\title{
SPEECH ACT IN AN INDONESIAN TELEVISION TALK SHOW (CONTENT ANALYSIS RESEARCH IN MATA NAJWA TALK SHOW AT METRO TV)
}

\author{
Tressyalina $^{1}$, Sakura Ridwan ${ }^{2}$ \\ ${ }^{1}$ Lecturer in Faculty of Language and Art, Universitas Negeri Padang, Indonesia \\ ${ }^{2}$ Universitas Negeri Jakarta, Indonesia \\ 1tressyalina@gmail.com, ${ }^{2}$ sakura@unj.co.id
}

\begin{abstract}
The objective of this research was to understand comprehensively about implementation of direct and indirect speech act in Mata Najwa talk shows on Metro TV. It was a qualitative research with content analysis method. The data were collected through indirect participant using observation and some document study were video recordings of audio-visual from www.matanajwa.com pages. It was started of January 2014 to March 2014. The analysis and interpretation of data, indicated that direct speech act mode was more dominant than indirect speech act. Direct speech act was conducted through speech of interrogative, declarative, and imperative. Indirect speech act was conducted through speech of declarative and interrogative for imperative mode.
\end{abstract}

Keywords: speech act; direct and indirect speech act; talk show; interrogative; declarative and imperative.

Indonesian teaching in higher education, especially in State University of Padang as subjects personality development aims to allow students be understand and use the Indonesian language is ideal and correct for trending purposes. However, based on the observation of researchers who also teach in the subject, syllabus Indonesian centered on the theory of language, so that the application of language skills especially speaking skills become less trained, although basically in the learning process associated with proficiency in speaking always covered at each meeting through the method of discussion. Thus, research studies of speech act in a Mata Najwa talk show, they are trained in speaking skills when applying such implication in language learning.

Searle (1969:16) states that the speech act is the basic unit of communication is carried out jointly with the principle of disclosure which shows a series of analytic relationships between ideas by speech. Then, Yule (2010: 133) explains that the speech act as an act done by a speaker through words, as requested, to rule, asking or informing. As well as premises Grundy (2000:49) by simplifying the concept of the speech act is an act of language. The same thing is described Geis (in Oswell, 2006:18) with him statement that speech acts have a relationship between the signifier and signified for individuals. Signifier can be used by the whole community of speakers and signified are made in special circumstances because of the language as a collective system.

Basically, the speech act theory by John L. Austin, a philosopher Oxford. Austin's work is revealed that there was a speech that not only leads to a statement only (Levinson, 2008:228), so he split the type of action that is performed when speaking locutionarry, illocutionary, and perlocutionary act (Levinson, 2008:108). 
However, a grouping of illocutionary speech acts Austin particular illocutionary speech acts according to Searle has drawbacks. This they are due two verbs are not synonymous must be marked with different illocutionary acts (Searle, 1969:8—9), so do not give a clear boundary between illocutionary acts and illocutionary verbs. Based on this consideration, then Searle also developed a theory that says the Austin illocutionary speech acts are assertive, directive, commissive, expressive and declarations. Therefore, this study focused on illocutionary speech act to review the terms of speech act directly and indirectly.

Speaking about the speech act directly and not directly it is known that in communicating one can use various types of sentences. The use of the sentences, there is a sentence in accordance with the mode and some are not. Yule revealed that when an utterance has a direct relationship between structures with function, then there is the use of direct speech act. However, if there is an indirect relationship between structures with function, then there is an indirect speech acts (Yule, 1996:54 - 55). The same was disclosed by Searle stating that most often found there was no correspondence between the three types of sentences (Collavin, 2011:386). This is in tune with the opinion of Grundy (2000:62) which suggests that the shape of interrogative sentences, not always used to ask, but also for the different modes. This is because some of interrogative sentences can be used to request or order. With regard to these examples, shall mean the similarity between the shapes of the sentence by sentence mode, which can be interpreted as a direct speech act. Bach and Hamish added that acts of direct speech allow insertion of words such as "please" (Ruytenbeek, 2014: 21). This means adapted not only types of sentences, but also contains the proposition that a demand.

The same thing also expressed by O'Keeffe et al (20011:87) which states that the speech act directly and indirectly linked to form sentences. These linkages can be seen in the following pattern declarative sentence to express something, imperative sentence to request or command, and interrogative sentence for asking. Based on the opinion of various experts above, it can be concluded that the direct speech act is a speech that has a similarity between the shapes of the sentence with the mode of delivery, whereas indirect speech act that is the difference in the mode used to form sentences.

The background and description of theories have been presented, the study aims to understand comprehensively (find, describe, analyze, and study based on relevant theory and the result of previous research) the depth of the speech act in terms of speech act directly and indirectly in Mata Najwa talk show on Indonesia television through various theories. The result of study are expected to provide insight to the students that the speech act can be performed in Indonesia language learning process. For example, presented the results of discussion in class about one of the topics that exist in Indonesian subject syllabus is not only based on his study in reading various references, but it also comes from observation of a case founded in daily activity. The observation aided by tools such as interviews instrument against those involved. Interview can be done through used of speech act, either directly or indirectly. So that, can be affirmed that the research about speech act in indonesian television talk show is important because it can be support of learning, especially in the aspect of Indonesian speaking skills in using is ideal and correctly accordance with its intended purpose. 


\section{METHOD}

This research is qualitative content analysis method. This means that the instrument is researcher with tools such as spread sheets instrument data collection. Data collection procedures Mata Najwa talk show aired by Metro TV every Wednesday at 20:05 to 21:30 pm through (1) an indirect participant observation, (2) documentation from January 2014 - March 2014 through the download page www.matanajwa.com, and (3) transcript data.

Data analysis procedures by using content analysis according to Myring's theory. First, it determines the theoretical definition of sub-focus research based on research questions are formulated, the illocutionary speech act, speech act directly and indirectly, as well as the principle of cooperation. Second, determine the sample with respect to research sub-focus categories based rules that have been formulated in the form of criteria that have been synthesized. For examples of couples disclosed in the form of speech, a good speech between the interviewer with the audience, as well as between the interviewer with the speaker. Then, the pair collected utterances and enter it in a certain code. Third, revised categories and coding based on check formative reliability, so that the data reduction. Fourth, do a summative check the reliability as the final step in making the interpretation of the text and as an evaluation through the use of quantitative analysis in the form of percentage amount.

\section{RESULTS}

Speech acts directly and indirectly mean reviewed based on the type of sentence that is used to connect to the mode of speech in a sentence stating something. The results related to speech acts directly and indirectly in the talk show Mata Najwa as follows.

First, speech acts directly with the utterances imperative. Speech acts directly with the utterances imperative found in this research is speech act of request, order, invites, and permit. Speech acts of request marked by verbs tolong (please) as a on the interviewer utterences to the sources “Tolong jelaskan Mas Roy strataginya!" (Please explain your strategy, Mr. Roy!); marked by verbs minta (requested) that looked at the utterances "Saya ingin minta komentar spesifik tentang pengawasan dari Panji dan Joko" (I want to request for specific comments about the supervision of Panji and Joko). Then, the speech acts of order marked by verbs silakan (please) in utterances "Mas Toto, silakan pertanyaan singkat-singkat untuk menguji, satu pertanyaan untuk semua" ("Mr. Toto, please short questions to test, one question for all) and marked with the sentences appeal which can be seen in the utterances "Mas Toto!" (Mr.Toto!). Further, the speech act of invites marked by particles mari (let) in utterances “Mari kita dengar sama-sama!" (Let's hear it together!) and be marked with adverbs boleh as in utterances "Boleh tepuk tangan” (May applause). Finally, the speech acts generally permit the sources requested permission from interviewer to respond something and permission on the matter marked by verbs silakan (please) with the utterances "Mas Teguh, silakan, Mas! (Mr. Teguh, pelase, Mr.); marked with a sentence appeal as in utterances "Mbak Rieke!” (Ms. Rieke) which means giving permission to the sources to provide feedback. 
Second, speech acts directly with the interrogative utterance. Speech acts directly with the imperatives of utterance found in this research is to ask speech acts by using pronouns asked, use of tone asked, affirming particles, and use the form dissenter. The use of pronouns asked characterized by apa (what) questions such as the utterances “Apa yang Anda temukan?” (What tou find?); marked by kapan (when) question to utterances “Sejak kapan Bu Rina?” (Since when, Ms Rina?); marked by mengapa/ kenapa (why) question to the utterances 'Kenapa mau susah-susah setelah hidup enak, Pak Nurdin?” (Why bother going after Mr. Nurdin good life?); marked by berapa (how much) question to the utterances "Anda kepala dusun membawahi berapa?" (How much citizens you charge?); marked by siapa (who) question to the utterances "Mereka ini siapa?" (These who are); marked by dimana (where) question to utterances "Kalau priorotas pembagunan Anda sekarang di Kabupaten Bangkalan itu titik beratnya di mana saja?" (If your development priorities in the Bangkalan District, where is the point?); marked by bagaimana (how) question to the uttrances "Bagaimana dengan ambisi pribadi?" (How about your personal ambisis?); marked by dari mana (from where) question to the utterances "Kalau Kang Raska, niatan awal untuk menjadi anggota DPRD itu dari mana?” (If Kang Raska, the initial intention to become a member of the Parliament from where?). Then, speech acts directly with the use of tones ask marked by rising intonation as in utterances “Menawarkan?” (Offering?).

As with the direct speech acts with the use of emphatic particles characterized by particles [-kah] in the utterances "Adakah forum tertentu yang Anda ciptakan untuk memastikan hubungan itu terus harmonis?" (Is there a particular forum that you created to ensure the continued harmonious relationship?); marked by particles conversation apa (what) to the utterances "Berani apa tidak?" (Da what is not?); marked by particles atau (or) the like in the utterances "RI satu itu harus menjadi impian atau ambisi setiap politisi?” (RI one that should be a dream or ambition of every politician?); marked by hidden particles options like the utterances "Pak Habibie, betul tidak itu, ada orang di sekeliling yang membisiki akhirnya Budiman dibebaskan belakangan?” (Mr. Habibie, is it true not, there are people around who whisper finally Budiman was released lately?). Furthermore, speech acts directly with use the form negation on the production of a positive answer which is marked by utterances "Anda merasa tidak penting sesungguhnya, Mbak Rieke?" (You was not important actually, Ms Rieke?); marked by negation to produce a negative answer as in utterances “Tapi, itu bukan setting-an Anda?” (But, it is not your setting?)

Third, direct speech acts with declarative utterances. Speech acts directly with declarative utterances are found in this study a speech act stated explanation, confirmation, reception, and speech acts of support. Use of speech acts directly using speech acts form the explanation appears on the use of the opening sentence ya (yes), begini (so), begitu (so), jadi (finished) or without the use of the said task, one such use in the example utterances "Ya..., maka dari itu jangan sampai tidak ada komunikasi sama yang diwakili... Jadi, jangan sampai tidak komunikasi lebih dari satu minggu kira-kira" (Yes ... and therefore do not get the same no communication represented... So, do not let the communication is not more than one week approximately). Then, the speech act directly to shape speech acts affirmation marked with the word benar (right), betul (correct), persis (exactly) to reply in the form of justification while the word was not to answer, the justification while no 
words to answer in the form of denial. This is one of them can be seen in the example of utterances "Persis" (Exactly). Furthermore, speech acts directly with the form of speech acts supporting marked with the word setuju (agree) which one of them as in utterances "Kementeriannya, setuju” (Ministry, agree). Next, speech acts directly by using the form speech acts states marked by the answers of question apa (what), siapa (who), di mana (where), dari mana (from where), bagaimana (how), and kapan (when) that which one example in the utterances "Dari keluarga" (From the family) as a response to the interviewer's questions that said "Kekuatannya dari mana, Mbak?" (Strength from where, Ms?).

Fourth, indirect speech acts with interrogative utterances. Indirect speech acts with interrogative utterances imperative mode found in this research is using interogatif embelan (interrogative) 'kan (isn't it) 'it is can be seen in the example of utterances "Dua puluh dua tahun baru lulus 'kan di Kairo University?" (Twenty-two years have recently graduated, at Cairo University, isn't it?); the use of interrogative through ya (isn't it) particles as in utterances “Jadi, sudah dua minggu milyaran berseliuran, ya?" (So, it's two weeks billions, isn't it? the use of interrogative sentences ellipsis section that used to require continued the statement as in the example "Dari seratus..." (From the hundred ...) spoken by the interviewer for asking the speaker to continue the utterances.

Fifth, indirect speech acts with declarative utterances. Indirect speech acts with declarative utterances to the imperative mode found in this research a speech act requesting feedback through mention of the negative facts with a low tone that looks at uteerances "Pak Marzuki, kalau kita bicara soal rekam jejak, saya ingat Anda dulu diperksa oleh Badan Kehormatan karena dinilai tidak etis menjadi bintang iklan produk (Mr. Marzuki, if we're talking about track record, I remember you used to be examined by the Ethics Council because it is considered unethical become advertisement product model); speech act indirectly with low intonation to ask for respond such as “Oke, Mas Toto" (Okay, Mr. Toto); the using of mentioning conclusion with low intonation to ask for confirmation towards the things which have been concluded based on the previous explanation that can be seen on the example "Semuanya baik, tapi aplikasinya yang kemudian belum sempurna" (Everything is good, but the application is not perfect yet).

Overall, based on the explanation about speech act which is seen from direct and indirect speech act, here are the results on Table 1.

Table 1. Speech Act based on Direct Speech and Indirect Speech in Mata Najwa Talkshow on Television

\begin{tabular}{llll}
\hline Speech Act & $\begin{array}{l}\text { Form of } \\
\text { Sentence }\end{array}$ & $\begin{array}{l}\text { Mood of } \\
\text { Sentence }\end{array}$ & $\begin{array}{l}\text { Markers of } \\
\text { Speech Act }\end{array}$ \\
\hline Direct & Imperative & Imperative & $\begin{array}{l}\text { The using of verb minta; verb silakan; and } \\
\text { verb mari }\end{array}$ \\
\cline { 2 - 5 } & Interrogative & Interrogative & $\begin{array}{l}\text { The using of interrogative pronouns such as } \\
\text { apa, siapa, mengapa/kenapa, kapan, } \\
\end{array}$ \\
& & $\begin{array}{l}\text { bagaimana, di mana, dari mana, berapa; } \\
\text { The using of interrogative intonation } \\
\text { through the increasing highly of intonation; } \\
\text { The using of eparticles confirmation } \\
\text { [-kah]; } \\
\text { The using of choices through the function } \\
\text { word apa, or, ellipsis particles atau }\end{array}$ \\
\hline
\end{tabular}




\begin{tabular}{|c|c|c|c|}
\hline & & & $\begin{array}{l}\text { The using of refusement form/negation tidak } \\
\text { for negative answers; } \\
\text { The using of refusement /negation form such } \\
\text { as bukant to indicate positive answers; }\end{array}$ \\
\hline & Declarative & Declarative & $\begin{array}{l}\text { The using of assertive illocution speech act } \\
\text { which states explanation; the existence of } \\
\text { confirmation; addressing/mentioning; form } \\
\text { of supporting towards the addressing of } \\
\text { statement. }\end{array}$ \\
\hline \multirow[t]{2}{*}{ Indirect } & Interrogative & Imperative & $\begin{array}{l}\text { The using interogatif embelan 'kan or } \\
\text { partikel ya to ask for justification yo the } \\
\text { propositiaon stated; } \\
\text { The using of the ellipsis the part of sentence } \\
\text { to request continue statement. }\end{array}$ \\
\hline & Declarative & Imperative & $\begin{array}{l}\text { The mentioning of negative facts with low } \\
\text { intonation to request for respond: } \\
\text { The addressing of name call with low } \\
\text { intonation to request for repond; } \\
\text { The mentioning of conclusion with low } \\
\text { intonation to request for confirmation. }\end{array}$ \\
\hline $\begin{array}{l}\text { Amount of } \\
\text { Percentation }\end{array}$ & & $\begin{array}{l}\text { Interviewer: } \\
\text { Direct }=77,6 \% \\
\text { Indirect }=22,4 \%\end{array}$ & $\begin{array}{l}\text { Resources: } \\
\text { Direct }=96,5 \% \\
\text { Indirect }=3,5 \%\end{array}$ \\
\hline
\end{tabular}

Based on the frequency of direct and indirect speech which are found in Mata Najwa talk show, it is concluded that the host and source used more of direct speech act than indirect speech act. This is related with the principle held by Mata Najwa talk show itself, which discusses about investigation and clarification towards the facts which have been revealed, so that the questions use more kinds of interrogative pronomina, then continued by the interrogative intonation, and kinds of negations. Thus, the answers will be in forms of explanation statements, emphasizement, and mentioning or addressing. The using of direct speech by the resource person, especially the real directive speech as the effect of confirmation towards the questions which are asked by the interviewer.

There is also the usage of indirect speech which is used a little bit more by the interviewer rather than the resource person. The interviewer used the indirect speech as an effort to get the information such as respond from the resource person towards something which has negative proposition for himself. Thus, based on the information given by the resource person by using supporting speech or explanation, the interviewer could get their point of view towards something or some cases. Unlike the using of indirect speech which has the least frequency for the recourse person. That speech happens because the resource person asks for the confirmation or justification towards the explanation he has given. That is why he does not show up often in the talk show.

\section{DISCUSIONS}

This section discuss about the speech act which is viewed from direct speech and indirect speech which have been analyzed in the previous section. Based on the eight episodes of Mata Najwa talk show, there are forms of imperative, interrogative, and 
declaration sentences which are delivered appropriate with the mood of the sentences. In the application, there is a bit differences in the using of this utterances. The interviewer as the speaker used direct speech in the amount of 77,6\% from 1404 pair of utterances, meanwhile the resource person as the hearer used direct speech in the amount of 96,5\% from 1312 pair of utterances. This happens because the interviewer generally uses the interrogative speech, confirmation, choice, or the using of refuse to intend the negative or positive answers, until the resource person used the assertive speech such as explanation, confirmation, or addressing speech to give information needed by the interviewer. Moreover, Mata Najwa talk show is a talk show with investigation basic which relies on confirmation towards certain cases which already happened. Sedorkin and McGregor opinions that no matter how short the answer is in answering the questions which use interrogative pronomina because this is part of the investigation before taking the next step to reveal which appears as explanation (Sedorkin and Gregor, 2002:69).

Direct speech in imperative sentences are stated by the sayer with the intention so that the target will do something suitable with the proposition of the sayer. The proposition itself is marked by the verb minta, verb silakan, verb tolong, adverbs boleh, vocative, and sentences which are stated in low intonation. Thus, direct speech is in forms of asking speech act and command speech act.

Direct speech act in interrogative mode is stated by the speaker for getting information from the hear based on the proposition that is stated. Thus, this direct speech act is interrogative mode speech act so that the proposition itself marked with the using of interrogative pronouns, interrogative intonation, forms of refuse, and interrogative addition sentences, the using of particles, and choice of answers. The interrogative pronouns of apa, siapa, berapa, mana, kapan and the using of multiple choice of answers indicate the feedback such as speech of addressing, meanwhile the interrogative pronouns mengapa/kenapa and bagaimana indicate the speech act of explanation statement from the target, so that this utterances is opened. The direct speech act of interrogative sentences with interrogative intonation which is spelled with the high intonation, forms of refuse, interogatif embelan sentences, or multiple choices of answers indicate the existence of answers which confirmation something, like ya, tidak, persis, benar, betul, bukan, and tepat. This means that the questions are closed. Related to the direct speech act in interrogative sentences, Edenborough (2002:21) stated that in certain form of interview, this statement has various type such as close questions that aimed to get the answer yes or not, include the question by using who, when, how,etc; the open question is delivered to get general information.

Direct speech act in declarative sentences are stated by the speaker to give information about something expected by the hearer. Thus, the application in speech act of explaining, addressing, confirmation, supporting, promising, giving thanks, apologizing, blaming, proclaiming, and speech of opening section. Based on that speech act, the relation with speech act in declarative sentences mode, so the things which are stated also have the meaning which are suitable with the proposition within.

Indirect speech act in eight episodes of Mata Najwa talk show can be analyzed and found that there are some differences of speech act in each episode. The interviewer as the speaker used the indirect speech act in the amount of 22,3\% from 1404 pair of utterance, meanwhile the resource person as the hearer used the indirect 
speech act in the amount of 3,37\% from 1305 pair of utterances. This is caused by the resource person as the informant, so that he states more about something rather than wanting the interviewer to do something. There is also indirect speech act which is meant to be imperative mood which are formed in declarative and interrogative sentences.

Indirect speech act in declarative sentences is used by the speaker with imperative mode. That mood is used to ask for respond, confirmation towards fact or reality given, even to continue the unfinished statements which is marked by the existence of quite long juncture as the mark that the speaker asks to continue it. This kind of speech act is also done by the resource person as the reaction of limited memory in explaining something, for example in this sentence, "Jadi, apakah Saudara mendapatkan grasi, apakah mendapat e...” (So, did you get the clemency, did you get a....). In this sentence which was said by one of resource person in Mata Najwa talk show, he indirectly asked his target person to continue his statement. That thing is marked by the juncture and the mark "e...” which indicates doubt. So that, direct speech act with mark using the ellpisis indicate existence of the incompleteness of grammatical structure can add to treasure of the theory Searle's (1969:36-39) and the result of previous research conducted by Zhang (2009:100 - 102) that can be concluded the speech act indirectly marked with a grammatical completely.

The indirect speech act in interrogative sentences is used by participant in imperative mode. That mode is used to ask for agreement towards the stated proposition. The mark is the using of particles ya in the end of the interrogative sentence and the using of refuse word interogatif embelan such as bukan/'kan. These marks are stated as forms of supporting towards the truth of proposition so that it indicates asking for agreement towards the related proposition. Unlike Syahrul's opinion (2008:79) which reveals that the words ya and 'kan are used for illocution speech act in asking for agreement towards something that has been revealed. This thing means that there is a new finding related with the using of indirect speech act, thus the using of ya and ' $k a n$ have the role as marker to ask for agreement, and also to ask for confirmation towards the proposition stated by the speaker. Besides, the particles ya can be one of ways in forming interrogative sentences, besides placing the forms of refuse such as bukan or tidak because in Tata Baku Bahasa Indonesia (Standard Language of Indonesia) stated that to form interrogative sentence from declarative sentence by adding the question particles apa, reserving the structure of words, using the word bukan or tidak, and adding intonation become higher (Alwi etc, 2003:358).

Based on the discussion that, this research has limited in the study. This is due to discuss the using speech act with content analysis method, so that only focus on the internal context. Thus, the further researchers can be analysis of speech act in talk show on television with ethnography method and critical discourse analysis, so that the speech act not only in the internal context but also external context, both culture of participants and culture of television media used as broadcasters.

\section{CONCLUSION}

As the field of interview, mechanism of Mata Najwa talk show move around questioning and answering, so that this talk show consist of direct and indirect speech 
act. Based research purpose about direct and indirect speech act, so the using of speech act founded in various sentence, both in the mode of declarative, interrogative, and imperative. Direct speech act in the form of sentence be used based on the sentence mode, at the same time indirect speech act be used with to do irregularities mode. The purpose irregularaties mode to do request for justification, request to continue statement unfinished, and requesting response or confirmation toward fact or conclusion given in order to their perspectives or actions can be understood. This is happens because the use in holding up question as the identification to the problem discussed in Mata Najwa talk show.

\section{REFERENCES}

Alwi, Hasan etc. (2003). Tata Bahasa Baku Bahasa Indonesia Edisi Ketiga. Jakarta: Balai Pustaka.

Collavin, Elena. (2011). “Speech Acts”, dalam Foundation of Pragmatics, eds. Wolfram Bublitz dan Neal R. Norrick. Jerman: Walter de Gruyter.

Edenborought, Robert. (2002). Effective Interviewing: A Handbook of Skills and Techniques. London: Kogan Page.

Grundy, Peter. (2000). Doing Pragmatics. New York: Oxford University Press.

Levinson, Stephen C. (2008). Pragmatics. Cambridge: Cambridge University Press.

O’Keeffe dkk, Anne. (2011). Introducing Pragmatics in Use. London dan New York: Routledge.

Oswell, David. (2006). Culture and Society: An Introduction to Cultural Studies. London: Sage.

Ruytenbeek, Nicolas. (2014). “Are Indirect Speech Act Always Conventional?” dalam Cognitive and Pragmatic Aspects of Speech Action, eds. Barbara Lewandowska-Tomaszczyk. Frankfurt: Peter Lang.

Searle, John R. (1969). Speech Acts: An Essay in the Philosophy of Language. Cambridge: Cambridge University Press.

Sedorkin, Gail dan Judy McGregor. (2002). Interviewing: A Guide for Journalist and Writers. Australia: Allen \& Unwin.

Syahrul R. (2008). Pragmatik Kesantunan Berbahasa: Menyibak Fenomena Berbahasa Indonesia Guru dan Siswa. Padang: UNP Press.

Yule, George. (1996). Pragmatics. New York: Oxford University Press, 1996.

Yule, George. (2010). The Study of Language. Cambridge: Cambridge University Press. 
Zhang, Fachun. (2009). "Motives of Indirectness in Daily Communication: An Asian Perspektive”, Asia Culture and History Journal, Volume 1, Nomor 2, Juli. 